\title{
Multivariate Analysis in Corn Cultivars Productivity Submitted to Fertilizations and Row Spacing
}

\author{
Anailson de Sousa Alves ${ }^{1}$, Tayd Dayvison Custódio Peixotoº ${ }^{2}$, Suedêmio de Lima Silva ${ }^{2}$, \\ Paulo Roberto de Souza Silveira ${ }^{2}$, Joaquim Odilon Pereira ${ }^{2} \&$ Francisco Aécio de Lima Pereira $^{2}$ \\ ${ }^{1}$ Department of Agronomy, State University of Maranhão, Balsas, MA, Brazil \\ ${ }^{2}$ Department of Environmental and Technological Sciences, Federal Rural University of Semi-Arido, Mossoró, \\ RN, Brazil \\ Correspondence: Tayd Dayvison Custódio Peixoto, Department of Environmental and Technological Sciences, \\ Federal Rural University of Semi-Arido, Mossoró, RN, Brazil. Tel: 55-849-9951-8863. E-mail: \\ dayvisonpeixoto@hotmail.com
}

Received: February 27, 2019

Accepted: April 1, $2019 \quad$ Online Published: May 31, 2019

doi:10.5539/jas.v11n7p96

URL: https://doi.org/10.5539/jas.v11n7p96

\begin{abstract}
The corn crop is important in various contexts of Brazilian agricultural production, both with respect to economic and social factors. The objective was to verify, through multivariate methods, the productive performance of two corn cultivars as a function of three types of fertilizations and two row spacing, identifying the correlation between the variables and the grouping between the evaluated treatments. The experiment was carried out at Experimental Farm Rafael Fernandes, Mossoró, Brazil. It was adopted a randomized block design at $3 \times 2 \times 2$ factorial experiment with four replications, the treatments consisted of three fertilizations (OF: Organic Fertilization; OMF: Organomineral Fertilization and MF: Mineral Fertilization), two cultivars of corn (Bras 3010 and Potiguar) and two row spacing $(80 \mathrm{~cm}$ and $50 \mathrm{~cm}$ ). The highest productivity was found with the use of organic fertilization, in the cultivar Potiguar, in the row spacing of $80 \mathrm{~cm}$. The final population, productivity and the mass of 1000 grains were the components that had the most effect in the evaluation of the data set. Each evaluated cultivar responded differently to the fertilizations and spacing evaluated. The agreement between the results of the cluster analysis and the main component analysis with the analysis of variance shows the adequacy of the multivariate statistical techniques used in this research.
\end{abstract}

Keywords: groupings, organomineral fertilization, space arrangement, Zea mays L.

\section{Introduction}

The corn crop is important in various contexts of Brazilian agricultural production, both with respect to economic and social factors. Among the crops grown in Brazil, the main cereal is corn (Zea mays L.) highlighting the volume of production and the socio-economic importance. It is estimated that in the 2017/18 harvest were grown 16.63 million hectares of this crop, in which they were produced 81.35 million tons of grain in the country according to CONAB (2018). Showing a national average productivity of 4,892 $\mathrm{kg} \mathrm{ha}^{-1}$, which can be considered low when compared to other countries such as USA and China.

Corn productivity in Brazil is considered low, and this is related to climatic conditions, spatial arrangement of plants, as well as to soil fertility and poor management practices (Chioderoli et al., 2012). In the state of Rio Grande do Norte, the planted area in 2017/18 was 40,900.0 hectares with average productivity of $473.0 \mathrm{~kg} \mathrm{ha}^{-1}$ (CONAB, 2018), indicating the urgent need for research related to crop management that result in higher productivity.

Positive effect of mineral fertilization was verified by several authors, with benefits in the number of grains per ear, mass of ear with and without husk, and productivity (Oliveira, Zucareli, Spolaor, Domingues, \& Ferreira, 2012); (Frazão, A. R. Silva, V. L. Silva, Oliveira, \& Corrêa, 2014). However, the increasing use of fertilizers to correct the problem of low availability of nutrients has a strong economic and environmental impact, leading to a scarcity of existing natural resources, causing some producers to opt for organic and organomineral fertilization.

In this context, the efficiency of the organic inputs tested as nutrient suppliers to the crops has been proven, it may be mentioned, among others, Silva, Galvão, Miranda, Silva, and Arnhold (2008); Santos et al. (2007); Mata, 
Silva, Ribeiro, Aférri, and Vieira (2010); Cancellier, Aférri, Adorian, and Rodrigues (2010) and Rodrigues, Broetto, Oliveira, and Rubio (2012) with corn crop. However, Costa et al. (2011a) verified that there was no difference between mineral, organic and organomineral fertilization on corn productivity. Lana, Rampim, and Vargas (2014a) also verified that organomineral and mineral fertilization provided the same productivity of corn grains.

The use of suitable spacings for each cultivar in each region can increase corn production components and productivity. Despite the advantages of using narrower spacing (Modolo, Carnieletto, Kolling, Trogello, \& Sgarbossa, 2010; Lana et al., 2014a), researchers have also demonstrated that corn crops, using spacings of up to $90 \mathrm{~cm}$ between rows, presented similar or higher agronomic and productive parameters compared to reduced spacings of up to $40 \mathrm{~cm}$ (Deparis, Lana, \& Frandoloso, 2007; Kappes et al., 2011).

Adaptability of cultivars to different sowing conditions is considered as one of the main factors for the good productivity of the corn crop. Including, Carvalho et al. (2005) affirm that despite the lower genetic potential, some varieties have presented similar average grain productivity when compared to hybrids.

In this sense, the multivariate analysis counts on the cluster analysis that identifies groups in multivariate data objects, which objective is to form groups with homogeneous properties among the sample elements, being able to identify the similarity characteristics between the cultivars and their productive components. The result can be presented in the form of a schematic diagram hierarchy called Dendrogram.

The objective of this study was to evaluate the productive performance of two corn cultivars as a function of three types of fertilizations and two row spacing, identifying the correlation between the variables and the grouping between the evaluated treatments.

\section{Material and Method}

\subsection{Experimental Area}

Experiment was carried out from June to October 2013, at Experimental Farm Rafael Fernandes, in the community of Alagoinha, belonging to the Federal Rural University of Semi-Árido (UFERSA). Located at Latitude $5^{\circ} 03^{\prime} 37^{\prime \prime} \mathrm{S}$ Longitude $37^{\circ} 23^{\prime} 50^{\prime \prime} \mathrm{W}$, with an average altitude of 72 meters and slope between 0 and $2 \%$, lying $20 \mathrm{~km}$ from the city of Mossoró, Brazil. The city of Mossoró is in the Rio Grande do Norte state Northeast region. According to W. Koeppen climate classification, the climate is BSwh' type, dry climate, very hot and rainy season in the summer lingering for fall, with an average annual temperature of $27.4{ }^{\circ} \mathrm{C}$, annual rainfall very irregular, averaging $673.9 \mathrm{~mm}$ and relative humidity 68.9\% (Pereira, Espínola Sobrinho, Oliveira, Melo, \& Vieira, 2011).

The soil of the experimental area was labeled according to the Brazilian soil classification as ARGISSOLO VERMELHO-AMARELO eutrófico latossólico de textura franco-arenosa (EMBRAPA, 2013), belonging predominantly to the Ultisol Order by U.S. Soil Taxonomy (USDA, 1999). The soil analysis, performed before the installation of the experiment in the $0-20 \mathrm{~cm}$ depth layer, collected 10 simple soil samples in the area, which later composed a single composite sample, being taken to the Soil Fertility and Nutrition of Plants Laboratory of UFERSA, for chemical and physical characterization.

Chemical analysis of the soil showed the following results: $\mathrm{pH} 4.8 ; 0.14 \mathrm{~g} \mathrm{~kg}^{-1} \mathrm{~N} ; 4.19 \mathrm{~g} \mathrm{~kg}^{-1}$ of organic matter; $8.1 \mathrm{mg} \mathrm{dm}^{-3} \mathrm{P} ; 40.1 \mathrm{mg} \mathrm{dm}^{-3} \mathrm{~K} ; 7.6 \mathrm{mg} \mathrm{dm}^{-3} \mathrm{Na} ; 0.52 \mathrm{cmolc} \mathrm{dm}^{-3} \mathrm{Ca} ; 0.44 \mathrm{cmolc} \mathrm{dm}^{-3} \mathrm{Mg} ; 0.15 \mathrm{cmolc} \mathrm{dm}^{-3} \mathrm{Al}$ and $0,83 \mathrm{cmolc} \mathrm{dm}^{-3} \mathrm{H}+\mathrm{Al}$. The physical analysis revealed that the soil presents $88 \%$ sand, $4 \%$ silt and $14 \%$ clay, soil density of $1.53 \mathrm{~g} \mathrm{~cm}^{-3}$, particle density of $2.64 \mathrm{~g} \mathrm{~cm}^{-3}$ and total porosity of $42.05 \%$.

In the area had small shrub native vegetation by the year 2010, which was subsequently removed, in 2011 was barred, scarified and cultivated with bean in conventional farming system. In 2012, the area was set aside. In the preparation of the soil, a plowing in the depth of $40 \mathrm{~cm}$ was carried out, followed by leveling gradation. A liming was carried out in the soil of the experimental area, raising the $\mathrm{pH}$ to a range adequate to the nutritional requirements of corn: 5.5 to 6.5 . It was distributed $2.5 \mathrm{t} \mathrm{ha}^{-1}$ of limestone with $12 \% \mathrm{MgO}$, applied 60 days before sowing and distributed at a depth of $0-10 \mathrm{~cm}$. The irrigation was twice a week done for the same period to assist the product reaction with the soil mineral particles.

\subsection{Experimental Design}

Experimental design was randomized blocks in factorial $3 \times 2 \times 2$, composed of three types of fertilizers (OF: Organic Fertilization; OMF: Organomineral Fertilization and MF: Mineral Fertilization), two row spacing, E1 $(80 \mathrm{~cm})$ and E2 $(50 \mathrm{~cm})$, and two cultivars of corn, hybrid Bras 3010 and the cultivar Potiguar, with four 
repetitions, totaling 48 experimental units of $4 \times 30 \mathrm{~m}$ each. The organic fertilization (OF) was performed as minimum recommendation of (EMPARN, 2010), corresponding to $10 \mathrm{t} \mathrm{ha}^{-1}$ of bovine manure.

Material was collected in the cattle sector from the Federal Rural University of Semi-Árido, which material was chemically analyzed and obtained the following characteristics: $\mathrm{pH} 7.7 ; 10.22 \mathrm{~g} \mathrm{~kg}^{-1} \mathrm{~N} ; 34.68 \mathrm{~g} \mathrm{~kg}^{-1}$ of organic matter; $806.7 \mathrm{mg} \mathrm{dm}^{-3} \mathrm{P} ; 5178.5 \mathrm{mg} \mathrm{dm}^{-3} \mathrm{~K} ; 1887.4 \mathrm{mg} \mathrm{dm}^{-3} \mathrm{Na} ; 9.6 \mathrm{cmolc} \mathrm{dm}^{-3} \mathrm{Ca} ; 8.3 \mathrm{cmolc} \mathrm{dm}^{-3} \mathrm{Mg} \mathrm{and}$ $0.44 \mathrm{cmolc} \mathrm{dm}^{-3} \mathrm{Al}$. The organomineral fertilization (OMF) was made by applying $50 \%$ of the recommended amount of manure recommended in organic fertilization (OF), $5 \mathrm{t} \mathrm{ha}^{-1}$, and $50 \%$ of the recommendation of mineral fertilizer (MF). The mineral fertilization (MF) was performed based on the parameters observed in the soil analysis and recommendation for the corn crop in the region due to an expected maximum productivity, 15 $\mathrm{kg} \mathrm{ha}^{-1}$ of Nitrogen, being applied in the foundation, and $60 \mathrm{~kg} \mathrm{ha}^{-1}$ in coverage fertilization. It was applied to 80 $\mathrm{kg}$ of phosphorus and $50 \mathrm{~kg} \mathrm{ha}^{-1}$ of potassium in the foundation. Before sowing operation, the seeds were treated with imidacloprid insecticide active principle and thiodicarb at a dose of $0.35 \mathrm{~L} \mathrm{ha}^{-1}$.

\subsection{Planting System}

Sowing was carried out on June 20, 2013, after the seeds of the hybrid Bras 3010, and the previously treated Potiguar corn variety were sown in the two row spacing: $80 \mathrm{~cm}$ and $50 \mathrm{~cm}$. The expected value was 69,200 and 52,250 seeds per hectare at each spacing used for a desired population of 50,000 plants per hectare. In the experiment was used a precision seeder, model chassis 2,800 mm, weight $656 \mathrm{~kg}$ and required power of $60 \mathrm{HP}$ operating at an average speed of about $5 \mathrm{~km} \mathrm{~h}^{-1}$, adjusted to 80 and $50 \mathrm{~cm}$ between rows, respectively.

\subsection{Irrigation System}

Irrigation water available at the Experimental Farm came from a well at Sandstone aquifer, characterized by presenting approximate depth of $1000 \mathrm{~m}$, with good quality electrical conductivity (ECw) of $0.58 \mathrm{dS} \mathrm{m}^{-1}$ and $\mathrm{pH}$ 7.5 being classified as good quality irrigation water (C1S1) according to USDA (1954). The irrigation system used was by spraying, powered by a three-phase hydraulic pump, with capacity of $7.5 \mathrm{hp}$ and maximum flow of $38 \mathrm{~m}^{3} \mathrm{~h}^{-1}$, consisting of 9 sidelines spaced $12 \mathrm{~m}$, with 8 sprinklers, each row also spaced $12 \mathrm{~m}$. The spray had $250 \mathrm{kPa}$ working pressure of $12 \mathrm{~m}$ range, flow rate of $528 \mathrm{~L} \mathrm{~h}^{-1}$ and height $2.5 \mathrm{~m}$ jet. With the meteorological station installed near the experiment was determined and applied to the amount of water necessary for each stage of culture. Irrigation was always done at night because the best application efficiency, lower drift caused by wind and consequently a better water use by the crop.

\subsection{Parameters Evaluated}

The following parameters were evaluated: final population (FP), obtained by counting the plants in the useful area of the plot, mass of ear with husk (MEWH), mass of ear without husk (MENH), ear length (EL), ear diameter (ED), determined using a digital caliper, mass of 1000 grains (M1000G), obtained from manual counting and subsequent digital weighing. As well, number of grains lines per ear (NGLE), determined by manual line counting, number of grains per ear (NGE), obtained by multiplying the count of the number of grains in a line by the total number of lines; mass of grains per ear (MGE), determined by digital weighing of the harvested grain of the collected ears. Also was estimated productivity $(\mathrm{P})$, which was obtained by weighing the grains harvested in the experimental plot area, with humidity corrected to $13.0 \%$, and adjustment of the data for $\mathrm{kg} \mathrm{ha}^{-1}$. It should be noted that the production components were determined at 120 days after full germination of plants, and 10 ears were collected at random from two central lines of the plot.

\subsubsection{Research Design}

Results obtained with respect to the production components and corn crop productivity were subjected to analysis of variance and to the multivariate methods by principal components analysis and cluster analysis in order to distinguish similar treatments and which variables interfered in this classification. In the present work, the significant interactions constant in the analysis of variance will not be discussed, acting only as a subsidy for the interpretation of the analysis performed through multivariate methods.

Application of the cluster analysis was preceded by a pre-treatment of the data, since the variables are of different scales. When pre-treatment is not done, the variables with higher numerical values will be more important in the calculation than the variables with lower numerical values. The pre-treatment used was the transformation $\mathrm{Z}$, which changed the measurements of each variable in such a way that the data set had zero mean and variance 1 . Then, for the analysis of clusters the transformed data were used, calculating the average Euclidean distances as measures of dissimilarity between treatments for the set of 10 variables studied. The final results of these clusters were presented in the form of a Dendrogram. The multivariate analyzes were performed with the aid of the BioEstat 5.3 Software (M. Ayres, M. Ayres Júnior, D. L. Ayres, \& Santos, 2007). 
In the Dendrogram obtained from the clustering analysis, the vertical axis represents the complete Euclidean distance, and the horizontal axis, the treatments. The Dendrogram shows the fusion points of the groups formed at each stage, where there are as many groups as the number of treatments, that is, each treatment forms a grouping. Initially, more treatments that are similar are grouped and fused into a single group.

\section{Result and Discussion}

\subsection{Statistics and Data Analysis}

According to the analysis of variance, significant differences were observed between fertilizations and cultivars for the mass of ear with and without husk, ear length, ear diameter, mass of grains per ear and for productivity. The interaction between fertilizations and row spacing significantly influenced the mass of ear with and without husk, ear diameter and mass of grains per ear. It was also verified that the interaction between cultivars and row spacing did not significantly affect any of the evaluated variables. On the other hand, the interaction between fertilizations, cultivars and row spacing significantly altered the mass of ear with and without husk, ear diameter and mass of grains per ear (Table 1).

Table 1. Values of the $\mathrm{F}$ test obtained in the analyzes of variance of evaluated characteristics as a function of fertilizations (F), corn cultivars (C) and row spacing (RS)

\begin{tabular}{llllllll}
\hline Sources of variation & $\mathrm{F}$ & $\mathrm{C}$ & $\mathrm{RS}$ & $\mathrm{F} \times \mathrm{C}$ & $\mathrm{F} \times \mathrm{RS}$ & $\mathrm{C} \times \mathrm{RS}$ & $\mathrm{F} \times \mathrm{C} \times \mathrm{RS}$ \\
\hline Final population & $1.84^{\mathrm{ns}}$ & $1.42^{\mathrm{ns}}$ & $9.88^{* *}$ & $1.83^{\mathrm{ns}}$ & $1.93^{\mathrm{ns}}$ & $0.62^{\mathrm{ns}}$ & $0.17^{\mathrm{ns}}$ \\
Productivity & $1.31^{\mathrm{ns}}$ & $6.10^{*}$ & $0.04^{\mathrm{ns}}$ & $4.02^{*}$ & $0.01^{\mathrm{ns}}$ & $0.34^{\mathrm{ns}}$ & $0.45^{\mathrm{ns}}$ \\
Mass of 1000 grains & $0.07^{\mathrm{ns}}$ & $4.17^{*}$ & $0.80^{\mathrm{ns}}$ & $1.13^{\mathrm{ns}}$ & $0.08^{\mathrm{ns}}$ & $0.04^{\mathrm{ns}}$ & $1.34^{\mathrm{ns}}$ \\
Mass of ear with husk & $7^{* *} 6^{* *}$ & $73.68^{* *}$ & $54.28^{* *}$ & $12.29^{* *}$ & $5.96^{* *}$ & $0.04^{\mathrm{ns}}$ & $5.15^{* *}$ \\
Mass of ear without husk & $7.75^{* *}$ & $50.23^{* *}$ & $49.33^{* *}$ & $10.91^{* *}$ & $4.94^{* *}$ & $0.00^{\mathrm{ns}}$ & $5.41^{* *}$ \\
Ear length & $5.18^{* *}$ & $6.67^{*}$ & $3.95^{*}$ & $4.73^{* *}$ & $1.28^{\mathrm{ns}}$ & $0.91^{\mathrm{ns}}$ & $1.20^{\mathrm{ns}}$ \\
Ear diameter & $3.40^{*}$ & $187.55^{* *}$ & $22.86^{* *}$ & $5.92^{* *}$ & $6.31^{* *}$ & $0.05^{\mathrm{ns}}$ & $3.88^{*}$ \\
Number of grains lines per ear & $1.03^{\mathrm{ns}}$ & $0.85^{\mathrm{ns}}$ & $2.12^{\mathrm{ns}}$ & $0.49^{\mathrm{ns}}$ & $1.33^{\mathrm{ns}}$ & $2.48^{\mathrm{ns}}$ & $1.79^{\mathrm{ns}}$ \\
Number of grains per ear & $1.31^{\mathrm{ns}}$ & $1.34^{\mathrm{ns}}$ & $11.88^{* *}$ & $6.11^{* *}$ & $1.17^{\mathrm{ns}}$ & $0.03^{\mathrm{ns}}$ & $2.86^{\mathrm{ns}}$ \\
Mass of grains per ear & $7.51^{* *}$ & $48.29^{* *}$ & $49.72^{* *}$ & $11.01^{* *}$ & $4.03^{*}$ & $0.09^{\mathrm{ns}}$ & $5.52^{* *}$ \\
\hline
\end{tabular}

Note. $* \mathrm{P}<0.05 ; * * \mathrm{P}<0.01 ;$ ns Not significant.

An original data matrix was elaborated with the different concentration levels of the ten production components evaluated. Subsequently, these data were standardized in order to unify the units where, from this, a correlation matrix was constructed that allows analyzing the association between variables. Table 2 shows the correlation matrix of the production components of corn cultivars.

Table 2. Correlation matrix of corn production components as a function of fertilizations (F), cultivars (C) and row spacing (RS)

\begin{tabular}{lllllllllll}
\hline & FP & P & M1000G & MEWH & MENH & EL & ED & NGLE & NGE & MGE \\
\hline PF & 1.00 & - & - & - & - & - & - & - & - & - \\
P & 0.12 & 1.00 & - & - & - & - & - & - & - & - \\
M1000G & -0.31 & 0.51 & 1.00 & - & - & - & - & - & - & - \\
MEWH & -0.50 & 0.57 & 0.59 & 1.00 & - & - & - & - & - & - \\
MENH & -0.50 & 0.55 & 0.57 & 1.00 & 1.00 & - & - & - & - & - \\
EL & 0.00 & 0.20 & -0.15 & 0.32 & 0.37 & 1.00 & - & - & - & - \\
ED & -0.44 & 0.63 & 0.64 & 0.92 & 0.89 & 0.00 & 1.00 & - & - & - \\
NGLE & -0.03 & -0.04 & -0.09 & -0.05 & -0.06 & 0.07 & -0.13 & 1.00 & - & - \\
NGE & -0.28 & 0.35 & -0.02 & 0.52 & 0.54 & 0.79 & 0.25 & 0.45 & 1.00 & - \\
MGE & -0.53 & 0.54 & 0.57 & 0.99 & 1.00 & 0.35 & 0.89 & -0.09 & 0.53 & 1.00 \\
\hline
\end{tabular}

Note. Final Population (FP), productivity (P), mass of 1000 grains (M1000G), mass of ear with husk (MEWH), mass of ear without husk (MENH), ear length (EL), ear diameter (ED), number of grains lines per ear (NGLE), number of grains per ear (NGE), and mass of grains per ear (MGE). 
Final population (FP) was negatively correlated with almost all other variables evaluated, less with productivity (P), with a low positive correlation between the two variables. Plant growth at the end of the cycle does not always reflect increased productivity, especially in corn, where surviving and productive plants at the end of their cycle can compensate for the negative effects of the absence of non-germinating or non-surviving plants. A greater soil space, increasing the interception of the root system by nutrients, receiving more light, increasing its photosynthetic capacity, all this can be reflected in an increase in the components of production and consequently in productivity.

Variables that contributed most to grain productivity of corn cultivars were ear diameter, mass of ear with and without husk, mass of grains per ear and mass of 1000 grains, with correlation estimates ranging from 0.51 and 0.63 . The mass of ear with and without husk were positively correlated, with five of the ten explanatory variables observed. These results corroborate with Entringer, Santos, Vettorazzi, Cunha, and Pereira (2014) that studying the direct and indirect relationships between the primary components of production and the productivity of super sweet corn ears found that the mean of mass of ear with husk was strongly correlated positively with six of the eight explanatory variables observed.

The ear diameter also presented positive correlation, and above 0.50 with productivity, mass of 1000 grains and the mass of ear with and without husk. These results differ from those found by Balbinot Junior, Backes, Alves, Ogliari, and Fonseca (2005) working with open pollinated varieties, observed that the number of grains per line was the component that presented the highest total correlation with the productivity $(0.58)$ when using two variables in the model, the components number of grains per line and number of grains lines per ear explained $47 \%$ of grain productivity variations.

It was also verified that the number of grains per ear correlated positively with the ear length and with the mass of ear with and without husk. It can be inferred that the greater the ear length and the mass of ear the greater the mass of grains per ear. The mass of grains per ear correlated directly with the mass of ear with and without husk, with correlations very close to 1.0. Correlating positively also with productivity, ear diameter, mass of 1000 grains and with the number of grains per ear. These results can be explained by the directly proportional correlation between these variables, because the greater mass of ear with and without husk, ear diameter, mass of 1000 grains and number of grains per ear, the greater mass of grains per ear.

In this sense, working with hybrids of corn, Mohammadi, Prasanna, \& Singh (2003) verified that mass of grains per ear and number of grains per ear were the most important components in predicting productivity. Carvalho, Borsato, and Viana (2001) observed that the parameters that contributed the most to the production per plant were the number of ears per plant and the mass of grains per ear, however, the authors did not include in the analysis the number of grains per ear.

\subsection{Percentage of Variance}

Results of the principal component analysis showed that the accumulated variance in the first three components composed by the final population (PF), productivity (P) and mass of 1000 grains (M1000G) retained $83.36 \%$ of the total information contained in the set of variables, the first variable explained $52.50 \%$ of the total variance, the second $19.21 \%$ and the third $11.65 \%$, respectively (Figure 1).

Although the final population did not correlate positively with the production components, the variable was responsible for more than half of the variation of the data, since all the evaluated components were extracted through the harvest of the plants that composed the final population. The productivity was responsible for approximately $20 \%$ of the variation of the data, considering that all the variables evaluated contributed directly to the composition of the different productivities obtained in the experiment.

The mass of 1000 grains retained approximately $12 \%$ of the total variation of the data in the analysis of main components, this variable is directly proportional to the productivity, because the increase in the mass of grains per ear induces the increase of the productivity. 


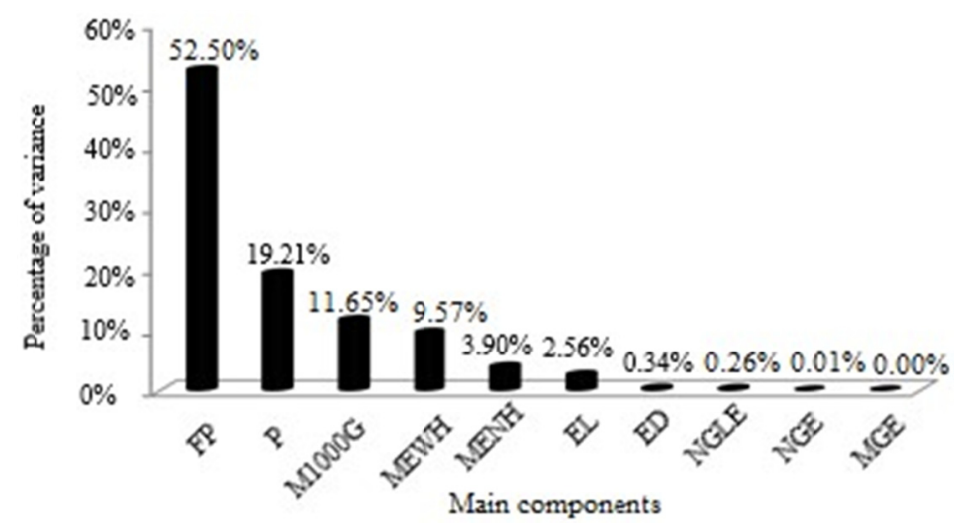

Figure 1. Percentage of variance of corn cultivars components as a function of fertilizations and row spacing

\subsection{Treatments Grouping}

The clustering analysis applied to the production components of the evaluated corn cultivars grouped the treatments in different groups, with a mean Euclidean distance of approximately $60 \%$.

These treatments are represented as follows: A: OBE1, organic fertilization, cultivar Bras 3010 and E1 spacing $(80 \mathrm{~cm})$; B: OBE2, organic fertilization, cultivar Bras 3010 and E2 spacing $(50 \mathrm{~cm})$; C: OPE1, organic fertilization, Potiguar cultivar and E1 spacing; D: OPE2, organic fertilization, Potiguar cultivar and E2 spacing; E: OMBE1, organomineral fertilization, cultivar Bras 3010 and E1 spacing. As well, F: OMBE2, organomineral fertilization, cultivar Bras 3010 and E2 spacing; G: OMPE1, organomineral fertilization, Potiguar cultivar and E1 spacing; H: OMPE2, organomineral fertilization, Potiguar cultivar and E2 spacing. As also, I: MBE1, mineral fertilization, cultivar Bras 3010 and E1 spacing; J: MBE2, mineral fertilization, cultivar Bras 3010 and E2 spacing; K: MPE1, mineral fertilization, Potiguar cultivar and E1 spacing; L: MPE2, mineral fertilization, Potiguar cultivar and E2 spacing (Figure 2).

Analyzing the groups formed, similarity between treatments A (OBE1) and B (OBE2) was observed, and this similarity is evidenced, considering that the same cultivar and the same type of fertilization, but at different row spacing composed the treatments. These treatments presented the lowest average productivity, 990 and $876 \mathrm{~kg}$ $\mathrm{ha}^{-1}$, respectively.

In the present study, it was evidenced that the hybrid Bras 3010 did not present positive responses when only organically fertilized. These results differ from those found by Cancellier et al. (2010) and Rodrigues et al. (2012), which verified positive responses of the components of organically fertilized corn with application of tanned bovine manure. It was also observed that there was no influence of the row spacing on the mass of 1000 grains and on the productivity of the crop, which was also evidenced by the observation of the Dendrogram, referring to cluster analysis (Figure 2).

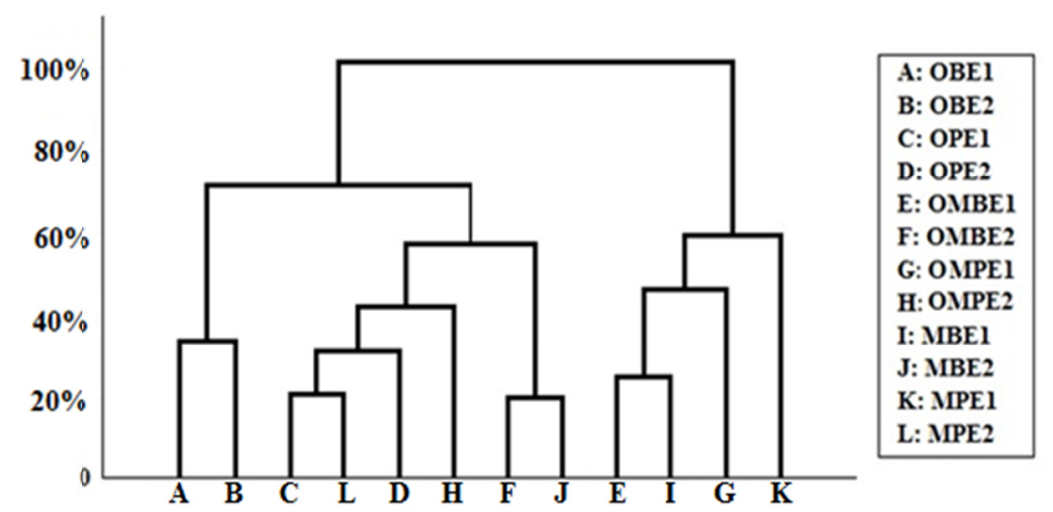

Figure 2. Dendrogram resulting from the clustering analysis of the 12 treatments, using the percentage of variation of average Euclidean distance as coefficient of similarity 
Lower Euclidean distances were observed, indicating the greatest similarities between C (OPE1) and L (MPE2) treatments. It was verified that the Potiguar variety when fertilized organic and mineral, in an isolated way, showed higher productivity than the hybrid Bras 3010. It was also evidenced by the multivariate analysis that these treatments were the ones that most correlated, indicating viability of the utilization of fertilization with bovine manure on the productivity of the regional corn variety in the western Potiguar region. These results still corroborate with Silva et al. (2008), Santos et al. (2007), and Mata et al. (2010), which verified significant effects on the production components and productivity of corn. The row spacing of 80 and $50 \mathrm{~cm}$ evaluated did not significantly influence the productivity of the cultivars, occurring similarity between the observed treatments.

Treatment $\mathrm{D}$ was the one responsible for the highest average value of productivity obtained in the experiment $\left(1,593 \mathrm{~kg} \mathrm{ha}^{-1}\right)$. D (OPE2) and H (OMPE2) treatments were observed to be close to treatments $\mathrm{C}$ and $\mathrm{L}$, and treatment $\mathrm{H}$ also presented high mean values of final population, mass of 1000 grains and productivity, which were the main components of the variation in the ten analyzed variables. However, there were no significant differences between organic and organomineral fertilization in the main components, possibly explaining the proximity of grouping between treatments. These results differ from those verified by Dania, Fagbola, \& Isitckhale (2012), which verified an increase in corn productivity with the use of organomineral fertilizer. Corroborating the results verified by Costa et al. (2011a), and Peixoto et al. (2019) which did not find significant differences in corn productivity when fertilized in mineral, organic and organomineral form.

The proximity between treatments $\mathrm{D}$ and $\mathrm{H}$ can also be explained because the treatments had the same spacing, where the spacing of $80 \mathrm{~cm}$ between rows influenced positively the mass of ear with and without husk, the ear diameter and the number of grains per ear. These results are contrary to those found by Kappes et al. (2011), which showed that the use of the reduced spacing $(45 \mathrm{~cm})$ was advantageous, increasing corn productivity by $15 \%$, compared to the $90 \mathrm{~cm}$ row spacing. However, the row spacing did not significantly influence the mass of 1000 grains and productivity, which together represented $32 \%$ of the variation in principal components analysis.

High similarities were found between treatments F (OMBE2) and J (MBE2), with a Euclidean distance of approximately $20 \%$, in which treatments were grouped into a single group. This grouping occurred with the same cultivar and at the same evaluated row spacing, cultivar Bras 3010 and $50 \mathrm{~cm}$ between rows, respectively. Evidence that the organic and organomineral fertilization in the crop of Bras 3010 cultivated in row spacing of $50 \mathrm{~cm}$ provided similarities in the components of production and productivity. However, they presented differences in relation to organic fertilization. These results corroborate with Lana, Rampim, Ohland, and Fávero (2014b), verifying that organomineral fertilization provided the same productivity of corn. However, Rodrigues et al. (2012) found that the use of organomineral fertilization based on humus did not provide higher productivity in the corn crop than the mineral source, however, the organic source was more cost-effective than organomineral and mineral sources.

Similarities between treatments E (OMBE1) and I (MBE1) were also found, forming a new group. In the cluster analysis, it was verified the separation of the treatments by cultivar and the row spacing in the group, where the similarity between the organic and organomineral fertilization in the cultivar Bras 3010 can be verified in the spacing of $80 \mathrm{~cm}$ between rows. It is observed that this similarity was smaller than the $50 \mathrm{~cm}$ spacing between rows for the same types of fertilizations. Fact that can be explained, because the treatments composed by the row spacing of $50 \mathrm{~cm}$ provided a larger final population, even though it did not reflect an increase in the production components and productivity of the evaluated cultivar.

According to the cluster analysis, in the visualization of the Dendrogram it can also be verified that the treatments G (OMPE1) and K (MPE1), even though they were close to each other, were grouped in isolated groups, being responsible for the largest Euclidean distances, $45 \%$ and $60 \%$, respectively, and, consequently, smaller similarities occurred in the experiment. The proximity between the treatments can be explained because no differences were observed between the organomineral and mineral fertilization in six of the ten components analyzed (EL, ED, NGLE, FP, M1000G and P). Meanwhile, the K treatment had the lowest similarity among the evaluated treatments, as it was responsible for the lowest final population obtained in the experiment $(19,375$ plants $\mathrm{ha}^{-1}$ ), being important to emphasize that this variable was responsible for more than $50 \%$ of the variation of ten analyzed variables. However, it showed a productivity of $1364 \mathrm{~kg} \mathrm{ha}^{-1}$, where the productive plants compensated the effects of the low density of plants in the treatment.

It is important to emphasize that in the formation of the groups, the greatest similarities were always observed between the same cultivar, inferring that most of the differences found may be due, mainly, to the evaluated corn cultivars. These results corroborate with Bertolini, Gamero, Salata, and Piffer (2008) which evaluated the performance of three corn cultivars by pre-sowing fertilization, compared to sowing fertilization, in no-tillage 
systems and reduced soil preparation, and verified through the analysis of variance that most of the differences found were mainly, because of corn cultivars used.

\section{Conclusion}

The organic fertilization associated to the row spacing of $80 \mathrm{~cm}$ provides greater productivity of the Potiguar variety, compared to the hybrid Bras 3010.

The final population, productivity and mass of 1000 grains were the main components in the evaluation of the data set.

The corn cultivars responded differently to the fertilizations and row spacing evaluated.

The concordance between the results of cluster analysis and principal component analysis with analysis of variance shows the adequacy of multivariate statistical techniques used in this research.

\section{References}

Ayres, M., Ayres Júnior, M., Ayres, D. L., \& Santos, A. A. S. (2007). BioEstat-Statistical applications in the areas of bio-medical sciences (Version 5.0). Belém, PA: Sociedade Civil Mamirauá, MCT-CNPq.

Balbinot Junior, A. A., Backes, R. L., Alves, A. C., Ogliari, J. B., \& Fonseca, J. A. (2005). Contribution of yield components on grain yield in maize open pollinated varieties. Brazilian Journal of Agroscience, 11(2), 161-166.

Bertolini, E. V., Gamero, C. A., Salata, A. C., \& Piffer, C. R. (2008). Anticipation of starter fertilizer application for corn under two soil tillage systems. Brazilian Journal of Soil Science, 32, 2355-2366.

Cancellier, L. L., Aférri, F. S., Adorian, G. C., \& Rodrigues, H. V. M. (2010). Influence of organic fertilization in line sowing on corn emergency and forage yield. Green Journal of Agroecology and Sustainable Development, 5(5), 25-32.

Carvalho, C. G. P., Borsato, R., Cruz, C. D., \& Viana, J. M. S. (2001). Path analysis under multicollinearity in S0 $\times$ S0 maize hybrids. Crop Breeding and Applied Biotechnology, 1(3), 263-270. https://doi.org/10.13082/ 1984- 7033.v01n03a06

Carvalho, H. W. L., Cardoso, M. J., Leal, M. L. S., Santos, M. X., Tabosa, J. N., \& Souza, E. M. (2005). Adaptability and stability of maize cultivars in Brazilian Northeast. Pesquisa Agropecuária Brasileira, 40(5), 471-477. https://doi.org/10.1590/S0100-204X2005000500008

Chioderoli, C. A., Mello, L. M. M., Grigolli, P. J., Furlani, C. E. A., Silva, J. O. R., \& Cesarin, A. L. (2012). Physycal properties of soil and yield of soybeans in corn braquiaria consortium. Brazilian Journal of Agricultural and Environmental Engineering, 16(1), 37-43. https://doi.org/10.1590/S1415-436620120001 00005

Costa, M. S. S. M., Pivetta, L. A., Costa, L. A. M., Pivetta, L. G., Castoldi, G., \& Steiner, F. (2011a). Soil physical attributes and corn yield as affected by soil managements and fertilization. Brazilian Journal of Agricultural and Environmental Engineering, 15(8), 810-815. https://doi.org/10.1590/S1415-436620110008 00007

Dania, S. O., Fagbola, O., \& Isitckhale, H. H. E. (2012). Effects of sawdust and organomineral fertilizer and their residual effect on the yield of maize on degraded soil. Pakistan Journal of Agricultural Sciences, 49(1), 61-66.

Deparis, G. A., Lana, M. C., \& Frandoloso, J. F. (2007). Row spacing and nitrogen and potassium fertilization in covering for the corn culture. Acta Scientiarum Agronomy, 29(4), 517-525.

EMPARN (Agricultural Research Company of Rio Grande do Norte). (2010). Technical recommendation to corn crop. Natal, RN: Agricultural Research Company of Rio Grande do Norte.

EMBRAPA (National Center of Soil Research). (2013). Brazilian System of Soil Classification (3rd ed.). Brasília, DF: Empresa Brasileira de Pesquisa Agropecuária.

Entringer, G. C., Santos, P. H. A. D., Vettorazzi, J. C. F., Cunha, K. S., \& Pereira, M. G. (2014). Correlation and path analysis for yield components of supersweet corn. Revista Ceres, 61(3), 356-361. https://doi.org/ 10.1590/S0034-737X2014000300009

Frazão, J. J., Silva, A. R., Silva, V. L., Oliveira, V. A., \& Corrêa, R. S. (2014). Enhanced efficiency nitrogen fertilizers and urea in corn. Brazilian Journal of Agricultural and Environmental Engineering, 18(12), 1262-1267. https://doi.org/10.1590/1807-1929/agriambi.v18n12p1262-1267 
Kappes, C., Andrade, J. A. C., Arf, O., Oliveira, A. C., Arf, M. V., \& Ferreira, J. P. (2011). Plants spatial arrangement for different maize hybrids. Pesquisa Agropecuária Tropical, 41(3), 348-359. https://doi.org/ 10.5216/pat.v41i3.9650

Lana, M. C., Rampim, L., \& Vargas, G. (2014a). Phosphate fertilization on corn with organomineral fertilizer in Oxisoil. Global Science and Technology, 07(1), 26-36. https://doi.org/10.14688/1984-3801/GST.V7 N1P26-36.

Lana, M. C., Rampim, L., Ohland, T., \& Fávero, F. (2014b). Spacing, population density and nitrogen fertilization in corn grown in an Oxisoil. Revista Ceres, 61(3), 424-433. https://doi.org/10.1590/S0034737X2014000300018

Mata, J. F., Silva, J. C., Ribeiro, J. F., Aférri, F. S., \& Vieira, L. M. (2010). Production of hybrid corn under doses of bovine manure. Pesquisa Aplicada \& Agrotecnologia, 3(3), 135-143.

Modolo, A. J., Carnieletto, R., Kolling, E. M., Trogello, E., \& Sgarbossa, M. (2010). Performance of corn hybrids at the Southwest of Paraná under different row spacing. Agronomic Science Journal, 41(3), 435-441.

Mohammadi, S. A., Prasanna, B. M., \& Singh, N. N. (2003). Sequential path model for determining interrelationship among grain yield related characters in maize. Crop Science, 43(5), 1690-1697. https://doi.org/10.2135/cropsci2003.1690

CONAB (National Supply Company). (2018). Follow-up of the Brazilian grain harvest-Harvest 2017/18. Brasília, DF: Companhia Nacional de Abastecimento.

Oliveira, M. A., Zucareli, C., Spolaor, L. T., Domingues, A. R., \& Ferreira, A. S. (2012). Agronomic performance of maize under mineral fertilizer and seed inoculation with rhizobacteria. Brazilian Journal of Agricultural and Environmental Engineering, 16(10), 1040-1046. https://doi.org/10.1590/S1415-436620 12001000002

Peixoto, T. D. C., Silva, S. L., Alves, A. S., Silveira, P. R. S., Pereira, J. O., \& Pereira, A. L. (2019). Biometric characteristics and productivity of Potiguar corn cultivar in different row spacing and fertilizations. Journal of Experimental Agriculture International, 30(2), 1-9. https://doi.org/10.9734/JEAI/2019/46521

Pereira, V. C., Espínola Sobrinho, J., Oliveira, A. D., Melo, T. K., \& Vieira, R. Y. M. (2011). Influence of phenomenon enso on rainfall in mossoró-rn. Enciclopédia Biosfera, 7(12), 1-13.

Rodrigues, T. R. D., Broetto, L., Oliveira, P. S. R., \& Rubio, F. (2012). Corn development due organic and mineral fertilizers. Bioscience Journal, 28(4), 509-514.

Santos, M. M., Galvão, J. C. C., Miranda, J. V., Ferreira, L. R., Melo, A. V., \& Fontanetti, A. (2007). Space between lines and nitrogen fertilizer in corn culture. Acta Scientiarum Agronomy, 29(4), 527-533. https://doi.org/10.4025/actasciagron.v29i4.415

Silva, R. G., Galvão, J. C. C., Miranda, J. V., Silva, D. G., \& Arnhold, E. (2008). Productivity of maize varieties in organic and conventional farming systems. Revista Caatinga, 21(2), 78-85.

USDA (United States Department of Agriculture). (1954). Diagnosis and improvement of saline and alkali soils (p. 60). Agriculture Handbook. Washington, DC: United States Department of Agriculture.

USDA (United States Department of Agriculture). (1999). Soil Taxonomy (2nd ed., p. 436). Agriculture Handbook. Washington, DC: United States Department of Agriculture.

\section{Copyrights}

Copyright for this article is retained by the author(s), with first publication rights granted to the journal.

This is an open-access article distributed under the terms and conditions of the Creative Commons Attribution license (http://creativecommons.org/licenses/by/4.0/). 